\title{
Analisis Ekspor Kayu Manis Indonesia ke Amerika Serikat
}

\author{
Yulmi Nur Asrini $^{1^{*}}$, Siti Hodijah ${ }^{2}$, Nurhayani ${ }^{3}$ \\ ${ }^{123)}$ Fakultas Ekonomi dan Bisnis, Universitas Jambi, Jl. Raya Jambi - Muara Bulian KM. 15, Muaro \\ Jambi, Jambi
}

\begin{tabular}{l|l|l|l} 
Diterima: 20-07-2021 & Direvisi: 31-07-2021 & Disetujui: 01-08-2021 & Dipublikasi: 03-08-2021
\end{tabular}

\begin{abstract}
This study aims to analyze the development of Indonesia's export volume of cinnamon to the United States, cinnamon export prices, exchange rates, and domestic cinnamon production. It also aims to analyze the influence of cinnamon export prices, exchange rates, and domestic cinnamon production on Indonesia's cinnamon exports to the United States from 2000-2017. The data used were obtained from the official website of Statistics Indonesia, United Nations Commodity Trade (COMTRADE), and the Plantation Office. The data analysis method used in this study is descriptive and quantitative methods with multiple linear regression analysis. Based on the multiple linear regression analysis results, it was concluded that simultaneously the prices of exported cinnamon, the exchange rate, and the domestic cinnamon production had a significant effect on the export of Indonesian cinnamon to the United States. Partially, the exchange rate and the production of domestic cinnamon had a significant effect. Still, the price of exported cinnamon did not significantly influence the export of Indonesian cinnamon to the United States.
\end{abstract}

Keywords: export, cinnamon, price, exchange rate, production

\begin{abstract}
Abstrak
Penelitian ini bertujuan untuk menganalisis perkembangan volume ekspor kayu manis Indonesia ke Amerika Serikat, harga kayu manis ekspor, nilai tukar dan produksi kayu manis domestik. Selain itu, penelitian ini juga menganalisis pengaruh harga kayu manis ekspor, nilai tukar dan produksi kayu manis domestik terhadap ekspor kayu manis Indonesia ke Amerika Serikat tahun 2000-2017. Data yang digunakan diperoleh dari website resmi Badan Pusat Statistik Indonesia, United Nation Commodity Trade (UN COMTRADE), dan Dinas Perkebunan. Metode analisis data yang digunakan dalam penelitian ini adalah metode analisis deskriptif dan kuantitatif dengan analisis regresi linier berganda. Berdasarkan hasil analisis regresi linier berganda, secara simultan harga kayu manis ekspor, nilai tukar dan produksi kayu manis domestik berpengaruh signifikan terhadap ekspor kayu manis Indonesia ke Amerika Serikat. Secara parsial, nilai tukar dan produksi kayu manis domestik berpengaruh signifikan tetapi harga kayu manis ekspor tidak berpengaruh signifikan terhadap ekspor kayu manis Indonesia ke Amerika Serikat.
\end{abstract}

Kata kunci: ekspor, kayu manis, harga, nilai tukar, produksi

\section{Pendahuluan}

Indonesia adalah salah satu negara yang menganut sistem perekonomian terbuka. Indonesia merupakan negara yang aktif dalam kegiatan perdagangan internasional dan mengandalkan kegiatan perdagangan internasional sebagai penggerak dalam pertumbuhan ekonomi. Berdasarkan data statistik dari Badan Pusat Statistik, hampir 5.000 macam produk dari Indonesia masuk ke pasar perdagangan internasional.

\footnotetext{
${ }^{*}$ Penulis korespondensi

Email: yulminurasrini@yahoo.com
} 
Sebagai negara yang masih berkembang, Indonesia mengandalkan potensi kekayaan sumber daya alam yang dimiliki untuk diperdagangkan di pasar internasional. Salah satu subsektor yang memiliki basis sumber daya alam adalah subsektor perkebunan. Komoditas perkebunan sebagian besar merupakan komoditas ekspor, sehingga kinerjanya sangat dipengaruhi oleh daya saing komoditas serta perubahan-perubahan yang terjadi baik di dalam negeri maupun dunia (Muttoharoh, dkk., 2018). Rencana penyusunan pembangunan perkebunan sangat ditentukan oleh posisi komoditas perkebunan Indonesia terhadap produksi dan posisi dunia. Berdasarkan hal tersebut, pengembangan subsektor perkebunan di Indonesia sangat diperlukan, mengingat subsektor perkebunan merupakan salah satu subsektor yang berbasiskan sumberdaya domestik. Penggunaan sumberdaya tersebut secara efisien dan efektif diharapkan mampu memberikan kontribusi yang baik untuk kinerja ekspor Indonesia.

Kelompok komoditi dari subsektor perkebunan yang memiliki potensi yang cukup baik di Indonesia yaitu komoditi rempah, aromatik, dan tanaman obat, sehingga Indonesia dijuluki sebagai "Mother of Spices" (ibu rempah). Pada tahun 2017, kontribusi komoditas ini mencapai 25,20 persen terhadap sektor pertanian tanaman tahunan (Badan Pusat Statistik, 2018).

Salah satu komoditas andalan Indonesia yang tergolong ke dalam jenis rempah adalah tanaman kayu manis. Kayu manis (Cinnamon burmannii) merupakan tanaman yang kulit batang, cabang, serta dahannya dapat digunakan sebagai bahan rempah-rempah, sejauh ini sebagian besar kayu manis masih diolah dalam bentuk gulungan kering kulit pohon dan pemasarannya lebih banyak untuk tujuan ekspor. Menurut Iskandar dkk., (dalam Martha Ayuningsih \& Setiawina, 2012) Indonesia memainkan peran penting di pasar kayu manis global, potensi perkebunan kayu manis yang dimiliki Indonesia mampu menjadikan Indonesia menempati urutan pertama sebagai negara produsen kayu manis dunia. Indonesia dapat dikatakan sudah memiliki kemampuan sebagai pengekspor kayu manis dalam pasar dunia dengan Republik Rakyat Tiongkok (RRT) sebagai negara pesaingnya yang juga merupakan produsen kayu manis.

Berdasarkan data United Nation Commodity Trade (2018), terjadi peningkatan nilai ekspor kayu manis ke dunia selama tahun 2013-2017. Pada tahun 2013, nilai ekspor kayu manis Indonesia mencapai US\$72,9 juta. Nilai ekspor menunjukkan pertumbuhan yang cukup baik dari US\$72,9 juta pada tahun 2013 menjadi US\$148,1 juta pada tahun 2017 dengan rata-rata pertumbuhan sebesar 27,8 persen per tahunnya. Untuk volume ekspor kayu manis, tahun 2013 mencapai 52.507 ton dan pada tahun 2017 mencapai 50.463 ton dengan rata-rata pertumbuhan sebesar 5,5 persen per tahunnya. Hal ini menunjukkan bahwa peranan komoditas kayu manis dapat diharapkan sebagai sumber devisa melalui kontribusinya terhadap nilai ekspor yang terus meningkat. Jika dilihat dari pergerakan nilai ekspor dan volume ekspor kayu manis Indonesia ke dunia, peningkatan nilai ekspor kayu manis lebih cepat dibandingkan dengan perubahan volume ekspornya.

Malian, dkk. (2003) mengungkapkan bahwa penawaran terhadap ekspor dipengaruhi oleh beberapa faktor, salah satunya produksi. Sebagai komoditas ekspor andalan Indonesia, produksi kayu manis domestik tentu akan sangat menentukan volume ekspornya. Berdasarkan data Statistik Perkebunan Indonesia (2015), produksi kayu manis domestik hanya sedikit mengalami peningkatan setiap tahunnya. Jumlah produksi kayu manis domestik tahun 2013 sebesar 92.030 ton dan untuk tahun 2017, total produksi kayu manis domestik sebesar 92.740 ton dengan rata-rata pertumbuhan hanya sebesar 0,7 persen per tahunnya. Produksi kayu manis tersebut ditujukan untuk memenuhi kebutuhan domestik dan juga permintaan dunia terhadap kayu manis. Pembenahan produksi sangat diperlukan guna menindaklanjuti peningkatan kuantitas dan kualitas produk yang maksimal, mengingat kebutuhan kayu manis di pasar dunia terus meningkat. 
Di pasar internasional, Indonesia merupakan salah satu penghasil kayu manis yang memasok sebagian besar produksi kayu manis di dunia. Sebagai negara produsen kayu manis dunia, ekspor kayu manis Indonesia sebagian besar (95\%) masih dalam bentuk gulungan dan broken (pecah), sedangkan dalam bentuk powder (bubuk) masih sangat sedikit. Adapun tujuan ekspor kayu manis domestik meliputi Amerika Serikat (46\%), Belanda (11\%), Jerman (4\%), dan Singapura (4\%) (Pribadi, 2016).

Amerika Serikat merupakan mitra dagang utama kayu manis Indonesia dengan pangsa pasar mencapai 46\%, tetapi selama periode 2014-2017 volume ekspor kayu manis Indonesia ke Amerika Serikat menunjukkan pertumbuhan yang cenderung menurun. Pada tahun 2014. volume ekspor kayu manis Indonesia ke Amerika Serikat sebesar 23.541 ton dan pada tahun 2017, volume ekspor hanya sebesar 17.502 ton. Rata-rata pertumbuhan ekspor kayu manis Indonesia ke Amerika Serikat mengalami penurunan sebesar 7,4 persen per tahunnya. Tetapi, hal ini justru berbanding terbalik dengan pertumbuhan harga kayu manis yang terus mengalami peningkatan. Pada tahun 2014 harga kayu manis adalah sebesar Rp22.902/kg dan terus mengalami peningkatan hingga mencapai Rp53.393/kg pada tahun 2017 dengan ratarata pertumbuhan sebesar 38,58 persen pertahunnya. Hal ini sejalan dengan diperolehnya Sertifikasi Geografis dan diakuinya kualitas kayu manis Kerinci yang merupakan sentra produksi utama kayu manis Indonesia oleh negara-negara di Eropa dan Amerika sebagai kayu manis kualitas dunia sehingga mampu mendorong harga kayu manis (Rifin, 2013). Sebagai produsen kayu manis dunia, peningkatan harga harusnya mampu mendorong volume ekspor komoditi ini. Tetapi tidak terjadi dalam hal ini, karena harga semakin meningkat namun volume ekspor justru mengalami penurunan.

Selain harga, nilai tukar juga merupakan hal penting yang harus diperhatikan. Nilai tukar merupakan komponen utama yang digunakan oleh suatu negara dalam melakukan perdagangan dengan negara lain sebagai acuan dalam transaksi perdagangan internasional. Saat ini, Indonesia menganut sistem kurs yang mengambang. Selama periode 2013-2015, kurs rupiah terhadap dolar terus melemah dengan nilai sebesar Rp12.189/US\$ pada tahun 2013 dan mencapai Rp13.548/US\$ di tahun 2017 dengan rata-rata perkembangan sebesar 9,60 persen per tahunnya. Sebagai eksportir, nilai tukar yang tinggi tentu menjadi kesempatan yang baik bagi Indonesia untuk melakukan kegiatan ekspor. Jika kurs mengalami depresiasi, yaitu nilai mata uang dalam negeri menurun dan nilai mata uang asing bertambah tinggi kursnya (harganya), maka eksportir akan gencar untuk meningkatkan ekspor.

Dengan melihat latar belakang yang telah diuraikan, penulis sangat tertarik untuk melakukan penelitian mengenai ekspor kayu manis Indonesia ke Amerika Serikat yang diberi judul Analisis Ekspor Kayu Manis Indonesia ke Amerika Serikat.

\section{Metode}

Jenis data yang digunakan dalam penelitian ini adalah data sekunder berupa data time series dari tahun 2000 sampai tahun 2017. Data yang digunakan diperoleh dari website resmi Badan Pusat Statistik Indonesia, United Nation Commodity Trade (UN COMTRADE), dan Dinas Perkebunan

Untuk menganalisis pengaruh harga kayu manis ekspor, nilai tukar, dan produksi kayu manis domestik terhadap ekspor kayu manis Indonesia ke Amerika selama periode 2000-2017, digunakan model regresi linier berganda dengan persamaan:

$$
V X=\beta 0+\beta_{1} P E t+\beta_{2} E R_{t}+\beta_{3} P R O D_{t}+e
$$

Keterangan:

$\begin{array}{ll}\mathrm{VX} & =\text { Volume ekspor kayu manis Indonesia ke Amerika Serikat } \\ \beta 0 & =\text { Konstanta } \\ P E_{t} & =\text { Harga kayu manis ekspor }\end{array}$

$P E_{t} \quad=$ Harga kayu manis ekspor 


$\begin{array}{ll}E R_{t} & =\text { Nilai tukar } \\ P R O D_{t} & =\text { Produksi kayu manis domestik } \\ \beta 1,2,3 & =\text { Koefisien regresi variabel X1,2,3 } \\ e & =\text { Variabel pengganggu }\end{array}$

\section{Hasil dan Pembahasan}

\section{Perkembangan Volume Ekspor Kayu Manis Indonesia ke Amerika Serikat}

Volume ekspor adalah jumlah atau berat komoditi kayu manis yang akan diekspor ke Amerika Serikat. Jika volume ekspor semakin tinggi, maka semakin besar nilai ekspor yang akan didapat. Hal ini tidak hanya akan menguntungkan para produsen atau petani kayu manis tetapi juga akan menguntungkan negara guna menambah devisa. Selama periode 2000-2017, volume ekspor kayu manis Indonesia ke Amerika Serikat memperlihatkan pertumbuhan yang fluktuatif. Hal ini dapat dilihat pada tabel perkembangan volume ekspor kayu manis Indonesia ke Amerika Serikat berikut ini:

Tabel 1. Perkembangan volume ekspor kayu manis Indonesia ke Amerika Serikat tahun 2000-2017 (ton)

\begin{tabular}{ccc}
\hline Tahun & Volume & Perkembangan \\
\hline 2000 & 13698 & - \\
2001 & 14363 & 4,85 \\
2002 & 14191 & $-1,20$ \\
2003 & 14342 & 1,06 \\
2004 & 15501 & 8,08 \\
2005 & 15324 & $-1,14$ \\
2006 & 19251 & 25,63 \\
2007 & 18313 & $-4,87$ \\
2008 & 20732 & 13,21 \\
2009 & 16214 & $-21,79$ \\
2010 & 20738 & 27,90 \\
2011 & 21169 & 2,08 \\
2012 & 15341 & $-27,53$ \\
2013 & 24145 & 57,39 \\
2014 & 23541 & $-2,50$ \\
2015 & 21221 & $-9,86$ \\
2016 & 21593 & 1,75 \\
2017 & 17502 & $-18,95$ \\
\hline Rata-rata & & 3,18 \\
\hline
\end{tabular}

Sumber: UNComtrade, 2018

Berdasarkan Tabel 1, perkembangan terendah terjadi pada tahun 2012 karena terjadi penurunan yang disebabkan oleh penurunan produksi kayu manis nasional. Sejak tahun 2008, produksi kayu manis nasional cenderung berkurang (Pribadi, 2016). Penurunan produksi itu diduga sejalan dengan penurunan luas areal serta rendahnya harga jual dan pendapatan yang diterima petani. Kondisi tersebut menyebabkan petani melakukan panen kayu manis hanya pada saat membutuhkan uang atau pada saat harga pasaran kayu manis membaik. Apabila harga kayu manis di pasaran sedang rendah, petani memilih untuk menunda memanen tanaman kayu manisnya, sehingga hal ini mempengaruhi volume ekspor kayu manis.

Pada tahun 2013, volume ekspor meningkat secara signifikan dan merupakan perkembangan tertinggi selama 2000-2017. Hal ini disebabkan oleh prospek pemasaran rempah di pasar internasional cukup baik, pertumbuhan konsumsi rempah dunia mencapai 10,2 persen tiap tahunnya (Suswono dalam Barus, 2013). Meskipun perkembangan volume 
ekspor kayu manis Indonesia ke Amerika Serikat selama periode 2000-2017 bergerak fluktuatif, namun volume ekspor kayu manis Indonesia ke Amerika Serikat ini menunjukkan pertumbuhan yang positif dengan rata-rata perkembangan sebesar 3,18 persen per tahunnya.

\section{Perkembangan Harga Kayu Manis Ekspor}

Harga merupakan nilai yang dinyatakan dalam satuan mata uang atau alat tukar terhadap suatu barang tertentu. Dalam kegiatan ekspor terutama pada sisi penawaran, harga berhubungan searah dengan jumlah barang yang ditawarkan. Semakin tinggi harga suatu komoditi maka jumlah komoditi yang ditawarkan juga akan semakin tinggi, dengan asumsi faktor lain selain harga yang mempengaruhi penawaran dianggap konstan. Berikut merupakan tabel perkembangan harga kayu manis ekspor tahun 2000-2017:

Tabel 2. Perkembangan harga kayu manis ekspor tahun 2000-2017

\begin{tabular}{ccc}
\hline Tahun & Harga & Perkembangan \\
\hline 2000 & 6189 & - \\
2001 & 5564 & $-10,10$ \\
2002 & 4962 & $-10,82$ \\
2003 & 4842 & $-2,42$ \\
2004 & 5444 & 12,43 \\
2005 & 5475 & 0,57 \\
2006 & 6197 & 13,19 \\
2007 & 7761 & 25,24 \\
2008 & 9625 & 24,02 \\
2009 & 8366 & $-13,08$ \\
2010 & 9971 & 19,18 \\
2011 & 12550 & 25,87 \\
2012 & 12107 & $-3,53$ \\
2013 & 17065 & 40,95 \\
2014 & 22902 & 34,20 \\
2015 & 27149 & 18,54 \\
2016 & 25891 & $-4,63$ \\
2017 & 53393 & 106,22 \\
\hline Rata-rata & & $\mathbf{1 6 , 2 3}$
\end{tabular}

Sumber: UNComtrade, 2018 (Data diolah)

Pada Tabel 2, dapat dilihat perkembangan harga kayu manis ekspor yang terus mengalami peningkatan. Namun, pada tahun 2009 harga kayu manis ekspor sempat mengalami penurunan sebesar 13,08 persen dengan harga kayu manis hanya sebesar Rp8.366/kg yang merupakan penurunan terendah selama periode 2000-2017. Hal ini merupakan akibat sistem alamiah di arena perdagangan sederhana saat kendali pemasaran dan harga kayu manis ada di tangan para tengkulak. Petani kayu manis dalam tata niaga kayu manis sangat tergantung pada pedagang pengumpul atau tengkulak sehingga petani tidak memiliki posisi tawar.

Peningkatan yang cukup signifikan terlihat sejak tahun 2011 saat harga kayu manis ekspor mencapai Rp12.550/kg, sementara pada tahun sebelumnya, harga kayu manis hanya sebesar Rp9.971/kg. Hal ini disebabkan oleh semakin beragamnya manfaat dari kayu manis, terutama untuk kesehatan sehingga kebutuhan akan kayu manis baik untuk diekspor maupun untuk konsumsi domestik semakin meningkat.

Peningkatan harga kayu manis ekspor terus berjalan hingga tahun 2017, dengan harga kayu manis ekspor mencapai Rp53.393/kg. Perkembangan harga kayu manis juga didorong oleh perolehan sertifikat Indikasi Geografis untuk kayu manis Kerinci dari Uni Eropa dan Amerika Serikat. Berdasarkan laporan hasil penelitian ilmuwan Amerika Serikat dan Prancis, diakui bahwa produksi kayu manis di Kerinci yang merupakan sentra produksi kayu manis 
Indonesia, memiliki kualitas terbaik dunia (Rifin, 2013). Diperolehnya sertifikat kualitas kayu manis terbaik membuat harga kayu manis ekspor terus mengalami peningkatan di pasar internasional.

\section{Perkembangan Nilai Tukar Rupiah terhadap Dolar}

Nilai tukar merupakan hal yang perlu diperhatikan dalam melakukan kegiatan ekspor karena nilai tukar merupakan perbandingan mata uang suatu negara terhadap mata uang negara lain yang digunakan dalam perdagangan internasional. Jadi, transaksi dalam perdagangan internasional harus menggunakan mata uang yang stabil atau mata uang yang tidak mengalami banyak perubahan seperti mata uang Dolar Amerika (US\$). Menurut Saunders dan Schumacher dalam Muttoharoh, dkk. (2018), alasan digunakan kurs US\$ dan konversinya terhadap rupiah adalah karena Dolar Amerika merupakan mata uang internasional.

Tabel 3. Perkembangan nilai tukar rupiah terhadap dolar tahun 2000-2017

\begin{tabular}{ccc}
\hline Tahun & Kurs & Perkembangan \\
\hline 2000 & 9595 & - \\
2001 & 10400 & $-14,04$ \\
2002 & 8940 & $-5,31$ \\
2003 & 8465 & 9,75 \\
2004 & 9290 & 5,81 \\
2005 & 9830 & $-8,24$ \\
2006 & 9020 & 4,42 \\
2007 & 9419 & 16,25 \\
2008 & 10950 & $-14,16$ \\
2009 & 9400 & $-4,35$ \\
2010 & 8991 & 0,86 \\
2011 & 9068 & 6,64 \\
2012 & 9670 & 26,05 \\
2013 & 12189 & 2,06 \\
2014 & 12440 & 10,89 \\
2015 & 13795 & $-2,60$ \\
2016 & 13436 & 0,83 \\
2017 & 13548 & $\mathbf{2 , 5 4}$ \\
\hline Rata-rata & &
\end{tabular}

Sumber: Badan Pusat Statistik, 2018

Berdasarkan Tabel 3, sejak tahun 2000-2017 perkembangan nilai tukar rupiah mengalami pertumbuhan sebesar 2,54 persen setiap tahunnya. Perkembangan terendah nilai tukar terhadap dolar terjadi pada tahun 2009 ketika rupiah mengalami penguatan dengan mengalami perkembangan sebesar negatif 14,16 persen. Hal ini merupakan keadaan yang baik dan menandakan bahwa rupiah mengalami apresiasi. Penyebabnya adalah kondisi semakin membaiknya ekonomi nasional dan juga dunia, setelah mengalami krisis global pada tahun 2008.

Pada tahun 2013, nilai tukar rupiah sangat lemah karena inflasi Indonesia terus bergerak dengan tak terkendali. Pada tahun 2013, inflasi meningkat hingga mencapai 8,38 persen dibandingkan periode-periode sebelumnya. Mulai tahun 2010 hingga 2013, impor sangat tinggi dan mencapai Rp15.561.675.869 yang menyebabkan nilai tukar rupiah melemah atau terjadi depresiasi.

Sejak tahun 2013-2015, nilai rupiah terhadap dolar tidak dapat dipertahankan di posisi di bawah Rp10.000. Nilai tukar rupiah yang kini berada pada kisaran Rp13.000/US\$ merupakan cerminan fundamental ekonomi Indonesia. Gubernur Bank Indonesia 
menjelaskan bahwa sulit untuk membawa rupiah kembali ke level Rp9.000/US\$ seperti 2012 lalu (Setyowati, 2017).

\section{Perkembangan Produksi Kayu Manis Domestik Tahun 2000-2017}

Indonesia adalah negara yang kaya akan sumber daya alam. Sebagian besar komoditas sektor perkebunan maupun pertanian merupakan komoditas ekspor, terutama sektor perkebunan. Sektor perkebunan memiliki peranan yang cukup baik dalam kegiatan ekspor Indonesia, baik itu perkebunan rakyat maupun perkebunan besar, karena subsektor ini memiliki basis sumber daya alam. Salah satu komoditas perkebunan rakyat yang dimiliki Indonesia, yaitu komoditi kayu manis yang mampu menjadikan negara ini sebagai negara produsen kayu manis dunia. Produksi kayu manis Indonesia tidak hanya mampu memenuhi kebutuhan domestik, baik untuk konsumsi maupun kebutuhan industri, tetapi juga kebutuhan dunia. Berikut merupakan tabel perkembangan produksi kayu manis Indonesia tahun 20002017.

Tabel 4. Perkembangan produksi kayu manis Indonesia tahun 2000-2017 (ton)

\begin{tabular}{ccc}
\hline Tahun & Produksi & Perkembangan \\
\hline 2000 & 45237 & - \\
2001 & 40635 & $-10,17$ \\
2002 & 45373 & 11,66 \\
2003 & 64830 & 42,88 \\
2004 & 99465 & 53,42 \\
2005 & 100775 & 1,32 \\
2006 & 94380 & $-6,35$ \\
2007 & 101880 & 7,95 \\
2008 & 102633 & 0,74 \\
2009 & 102680 & 0,05 \\
2010 & 88104 & $-14,20$ \\
2011 & 90276 & 2,47 \\
2012 & 89577 & $-0,77$ \\
2013 & 92030 & 2,74 \\
2014 & 91400 & $-0,68$ \\
2015 & 91500 & 0,11 \\
2016 & 91144 & $-0,39$ \\
2017 & 92740 & 1,75 \\
\hline Rata-rata & & $\mathbf{5 , 4 4}$ \\
\hline
\end{tabular}

Sumber: Badan Pusat Statistik, 2018

Berdasarkan Tabel 4, perkembangan produksi kayu manis Indonesia terbesar terjadi pada tahun 2004, yaitu sebesar 53,42 persen dan mengalami peningkatan dari tahun 2003 (10,54 persen). Peningkatan ini karena areal kayu manis mencapai puncaknya pada periode 1999-2004 dengan areal tanam terluas pada tahun 2004 (Pribadi, 2016).

Perkembangan produksi kayu manis terendah terjadi pada tahun 2010, yaitu sebesar 14, 20 persen dari tahun sebelumnya, dengan total produksi di tahun ini hanya sebesar 88.104 ton. Turunnya produksi kayu manis pada tahun ini turut dipengaruhi oleh berkurangnya luas lahan perkebunan kayu manis. Fluktuasi jumlah luas tanam ini disebabkan karena para petani mengonversikan lahannya dengan tanaman lain seperti tanaman hortikultura, palawija, dan tanaman perkebunan lainnya. 


\section{Pengaruh Harga, Nilai Tukar Dan Produksi Terhadap Ekspor Kayu Manis Indonesia Ke Amerika Serikat}

Model regresi pengaruh harga kayu manis ekspor, nilai tukar, dan produksi kayu manis domestik terhadap volume ekspor kayu manis Indonesia ke Amerika Serikat, digunakan model .

Tabel 5. Hasil estimasi regresi

\begin{tabular}{lcccc}
\hline \multicolumn{1}{c}{ Variable } & Coefficient & Std. Error & $\begin{array}{c}\text { t- } \\
\text { Statistic }\end{array}$ & Prob. \\
\hline C & -957.069 & 6250.201 & 0.153126 & 0.8805 \\
PE & -0.080857 & 0.094524 & -0.85541 & 0.4067 \\
ER & 1.325014 & 0.643452 & 2.059227 & 0.0586 \\
PROD & 0.075138 & 0.032397 & 2.319249 & 0.0360 \\
& & & & \\
\hline R-squared & 0.505882 & Mean dependent var & 18176.61 \\
Adjusted R-squared & 0.4 & S.D. dependent var & 3441.881 \\
S.E. of regression & 2666.07 & Akaike info criterion & 18.80773 \\
Sum squared resid & 99511027 & Schwarz criterion & 19.00559 \\
Log likelihood & -165.2696 & Hannan-Quinn criter. & 18.83501 \\
F-statistic & 4.777771 & Durbin-Watson stat & 1.868625 \\
Prob(F-statistic) & 0.017006 & & \\
\hline
\end{tabular}

\section{Uji asumsi klasik}

\section{Multikolinearitas}

Uji multikolinearitas dilakukan untuk mengetahui ada tidaknya hubungan linier yang sempurna di antara beberapa atau semua variabel yang menjelaskan dari model regresi. Indikasi gejala multikolinearitas dapat diketahui dari korelasi derajat nol tinggi antara peubah bebas. Jika nilai Centered VIF $>10$ maka model terindikasi gejala multikolinearitas. Hasil uji multikolinearitas diberikan pada Tabel 6.

Tabel 6. Uji Multikolinearitas

\begin{tabular}{llll}
\hline Variable & $\begin{array}{l}\text { Coefficient } \\
\text { Variance }\end{array}$ & $\begin{array}{l}\text { Uncentered } \\
\text { VIF }\end{array}$ & $\begin{array}{l}\text { Centered } \\
\text { VIF }\end{array}$ \\
\hline C & 39065018 & 98.92758 & NA \\
PE & 0.008935 & 7.436067 & 3.228752 \\
ER & 0.414030 & 118.0915 & 3.172921 \\
PROD & 0.001050 & 20.14320 & 1.073244 \\
\hline
\end{tabular}

Berdasarkan Tabel 6, nilai centered VIF untuk variabel harga kayu manis ekspor sebesar 3.228752, nilai centered VIF untuk variabel nilai tukar sebesar 3.172921, dan nilai centered VIF untuk variabel produksi kayu manis domestik sebesar 1.073244. Nilai centered VIF semua variabel < 10 dan berarti tidak terjadi multikolinearitas antara harga kayu manis ekspor, nilai tukar, dan produksi kayu manis domestik.

\section{Uji heteroskedastisitas}

Uji heteroskedastisitas terjadi saat residual dan nilai prediksi mempunyai pola hubungan. Pola hubungan ini tidak hanya sebatas hubungan linier tetapi juga berbeda. Apabila nilai probabilitas F-hitung $>0,05$, maka tidak terindikasi adanya gejala heteroskedastisitas. Tabel 7 memberikan hasil uji heteroskedastisitas 
Tabel 7. Uji heteroskedastisitas

\begin{tabular}{lcll}
\hline Heteroskedasticity Test: Breusch-Pagan-Godfrey & \\
\hline F-statistic & 1.215 .580 & Prob. F(3,14) & 0.3406 \\
Obs ${ }^{*}$-squared & 3.719 .742 & Prob. Chi-Square(3) & 0.2934 \\
Scaled explained SS & 1.332 .697 & Prob. Chi-Square(3) & 0.7214 \\
\hline
\end{tabular}

Berdasarkan Tabel 7, probabilitas Chi-Square lebih besar dari nilai $\alpha$ yang dipilih yaitu $0.2934>0,05$ dan tidak mengalami signifikansi dalam model pengujian BreuschPagan-Godfrey. Hal ini menunjukkan bahwa variabel harga kayu manis ekspor, nilai tukar, dan produksi kayu manis domestik terhadap volume ekspor kayu manis Indonesia ke Amerika Serikat tidak terdapat heteroskedastisitas.

\section{Uji autokorelasi}

Untuk mengetahui indikasi gejala autokorelasi digunakan metode Breusch-Godfrey atau uji Lagrange Multiplier, yang mana jika probabilita $<0,05$ maka terindikasi gejala autokorelasi. Tabel 8 memberikan hasil uji autokorelasi.

Tabel 8. Uji autokorelasi

\begin{tabular}{lcll}
\hline \multicolumn{4}{l}{ Breusch-Godfrey Serial Correlation LM Test: } \\
\hline F-statistic & 0.179975 & Prob. F(2,12) & 0.8375 \\
Obs*R-squared & 0.524200 & Prob. Chi-Square(2) & 0.7694 \\
\hline
\end{tabular}

Berdasarkan Tabel 8, nilai probabilitas Chi-Square sebesar 0,7694>0.05 dan tidak mengalami signifikansi dalam model pengujian Breusch-Godfrey Serial Correlation LM Test ini berarti variabel harga, nilai tukar, dan produksi terhadap ekspor kayu manis Indonesia ke Amerika Serikat tidak terdapat autokorelasi.

\section{Uji normalitas}

Uji normalitas dimaksudkan untuk mengetahui apakah residual yang dibentuk model regresi linier berdistribusi normal atau tidak dengan asumsi klasik pendekatan OLS. Gambar 1 memberikan hasil uji normalitas.

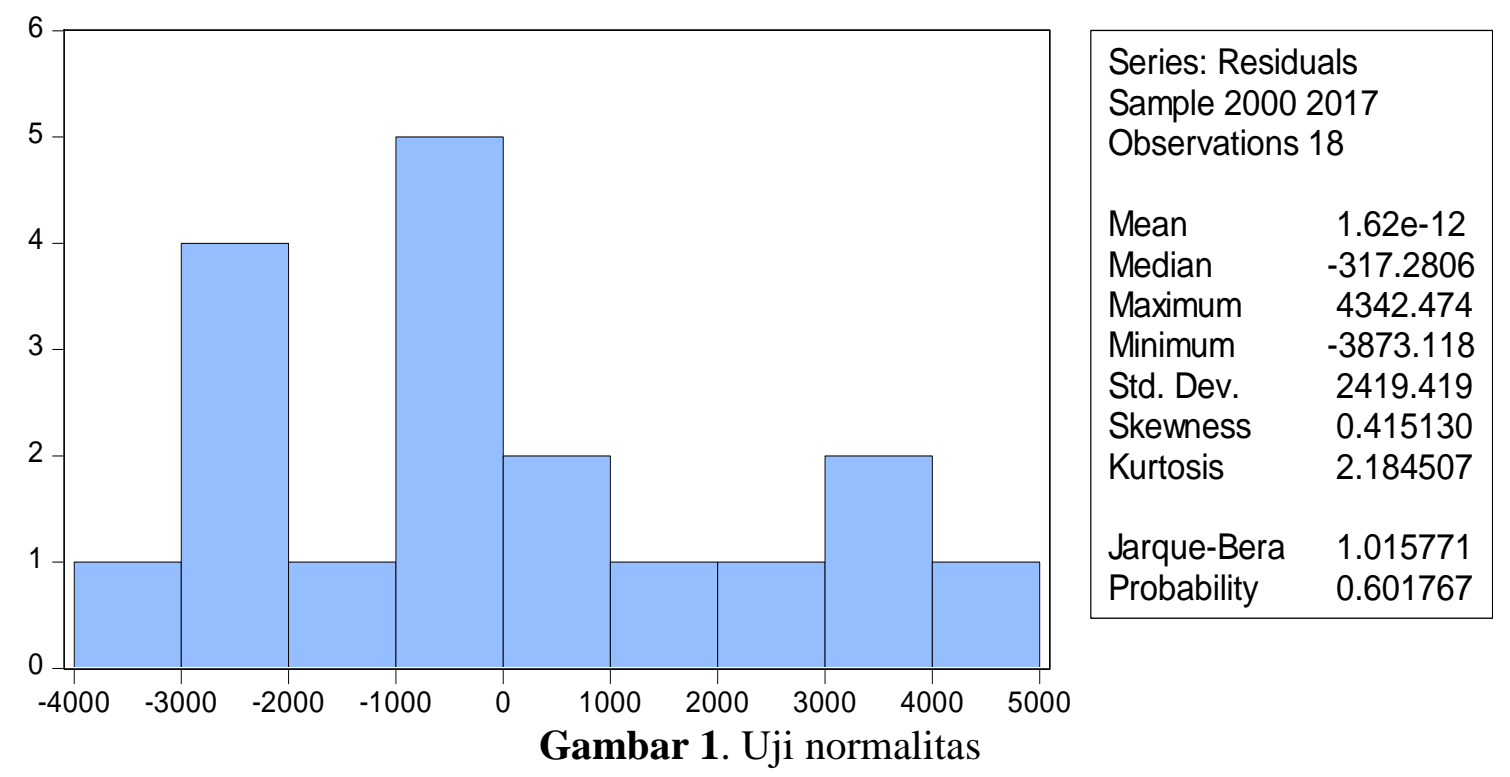

Berdasarkan Gambar 1, nilai probabilita JB hitung lebih besar dari nilai probabilitas $\alpha$ $=5 \%$ dalam pendekatan Jarque-Bera test maka hipotesis yang menyatakan bahwa variabel pengganggu adalah berdistribusi normal diterima. 


\section{Pengujian Hipotesis}

\section{Uji-F}

Uji F statistik dilakukan untuk melihat pengaruh variabel independen/bebas secara simultan terhadap variabel dependen/terikat. Berdasarkan Tabel 5 terlihat nilai F-statistic sebesar 4,77771 dengan probabilita $0,017006<\alpha=0,05$. Dengan demikian $\mathrm{H}_{0}$ ditolak dan $\mathrm{H}_{\mathrm{a}}$ diterima. Hal ini berarti harga kayu manis ekspor, nilai tukar, dan produksi kayu manis domestik secara bersama-sama berpengaruh signifikan terhadap volume ekspor kayu manis Indonesia periode 2000-2017.

\section{Uji $t$}

Uji t digunakan untuk menganalisis hipotesis secara parsial guna mengetahui seberapa besar signifikan atau tidak signifikannya pengaruh masing-masing variabel independen/bebas terhadap variabel dependen/terikat. Berdasarkan hasil regresi yang diperoleh pada Tabel 5, diberikan sebagai berikut:

Harga Kayu Manis Ekspor. Dari hasil perhitungan diperoleh nilai t hitung untuk variabel independen harga kayu manis sebesar 0,855410 dengan probabilita 0,4067 ( $>\alpha=$ 10\%). Dengan demikian $\mathrm{H}_{0}$ diterima dan $\mathrm{H}_{\mathrm{a}}$ ditolak dan berarti harga kayu manis tidak berpengaruh signifikan terhadap ekspor kayu manis Indonesia ke Amerika Serikat. Hal ini juga sesuai dengan penelitian yang dilakukan oleh Elisha (2015) yang menemukan bahwa variabel harga tidak berpengaruh signifikan terhadap volume ekspor kopi Indonesia ke Amerika Serikat.

Nilai Tukar. Hasil regresi menunjukkan nilai t hitung untuk kurs adalah 2,059227 dengan tingkat kepercayaan $95 \%$ dan $\alpha=5 \%$ df $=14$ dengan probabilita $0,0586(<\alpha=10 \%)$. Dengan demikian $\mathrm{H}_{0}$ ditolak dan $\mathrm{H}_{\mathrm{a}}$ diterima yang artinya kurs memiliki pengaruh yang signifikan terhadap ekspor kayu manis Indonesia ke Amerika Serikat. Penelitian ini pun sejalan dengan penelitian yang dilakukan oleh Martha Ayuningsih dan Setiawina (2014) yang menyatakan bahwa variabel nilai tukar Rupiah berpengaruh signifikan terhadap ekspor kayu manis Indonesia periode 1992-2011.

Variabel nilai tukar memiliki nilai koefisien sebesar 1,325014 dan memiliki arti bahwa nilai tukar berpengaruh positif terhadap ekspor kayu manis Indonesia ke Amerika Serikat. Jika nilai tukar mengalami peningkatan sebesar 1 rupiah, maka volume ekspor kayu manis Indonesia ke Amerika Serikat mengalami peningkatan sebesar 1.325014 ton, dengan asumsi variabel lain konstan.

Produksi Kayu Manis. Hasil regresi menunjukkan nilai t hitung untuk produksi kayu manis domestik sebesar 2,319249 dengan probabilita 0,0386 $(<\alpha=5 \%)$. Dengan demikian $\mathrm{H}_{0}$ ditolak dan $\mathrm{H}_{\mathrm{a}}$ diterima yang artinya produksi berpengaruh positif dan signifikan terhadap ekspor kayu manis Indonesia ke Amerika Serikat.

Variabel produksi kayu manis domestik memiliki nilai koefisien sebesar 0,075138 dan berarti bahwa produksi kayu manis domestik memiliki pengaruh positif terhadap ekspor kayu manis Indonesia ke Amerika Serikat. Jika produksi mengalami peningkatan sebesar 1 ton, maka volume ekspor kayu manis Indonesia ke Amerika Serikat mengalami peningkatan sebesar 1.325014 ton, dengan asumsi variabel lain konstan.

Hasil estimasi ini sesuai dengan penelitian sebelumnya yang dilakukan oleh Mufidah dan Fahmi (2014), yang menunjukkan bahwa produksi kayu manis domestik berpengaruh signifikan terhadap ekspor kayu manis Indonesia ke negara tujuan terbesar.

\section{Koefisien determinasi $\left(R^{2}\right)$}

Koefisien determinasi $\left(\mathrm{R}^{2}\right)$ adalah ukuran yang menginformasikan tentang garis regresi sampel sesuai dengan datanya atau suatu ukuran yang menunjukkan besarnya 
sumbangan dari variabel independen/bebas terhadap variabel dependen/terikat. Berdasarkan hasil perhitungan statistik, besarnya koefisien determinasi $\left(R^{2}\right)$ adalah 0,505882 , sehingga nilai determinan $\left(R^{2}\right)$ menunjukkan bahwa pengaruh seluruh variabel independen/bebas, yaitu harga kayu manis ekspor, nilai tukar, dan produksi kayu manis domestik terhadap perubahan nilai variabel dependen yaitu volume ekspor kayu manis Indonesia ke Amerika Serikat adalah sebesar 50,58 persen. Sementara itu, sisanya sebesar 49,42 persen dijelaskan oleh faktor-faktor lain yang tidak masuk dalam model regresi.

\section{Kesimpulan dan Saran}

\section{Kesimpulan}

Selama periode 2000 - 2017, volume ekspor kayu manis Indonesia ke Amerika Serikat, harga kayu manis ekspor, nilai tukar, dan produksi mengalami pertumbuhan yang positif. Secara simultan variabel harga, nilai tukar, dan produksi berpengaruh signifikan terhadap ekspor kayu manis Indonesia ke Amerika, dan secara parsial, variabel nilai tukar dan produksi berpengaruh positif dan signifikan terhadap volume ekspor kayu manis Indonesia ke Amerika Serikat, namun variabel harga berpengaruh negatif dan tidak signifikan terhadap volume ekspor kayu manis Indonesia ke Amerika Serikat.

\section{Saran}

Peningkatan volume ekspor dapat dilakukan dan ditempuh dengan cara meningkatkan produksi kayu manis domestik. Hal ini tidak terlepas dari peran pemerintah, seperti memberikan bantuan berupa bibit unggul kepada para petani kayu manis sehingga petani mampu menghasilkan kayu manis dengan proses pemanenan yang tidak memakan waktu lama. Pemerintah juga diharapkan dapat memberikan bimbingan pasca panen kepada para petani sehingga pengetahuan petani terhadap budi daya kayu manis semakin membaik dan kualitas/mutu kayu manis yang dihasilkan juga semakin baik. Selain itu, inovasi dari para produsen diperlukan untuk menciptakan berbagai produk olahan dari kayu manis sehingga nilai tambah dan harga yang tercipta di pasar semakin tinggi dan komoditas ekspor bukan lagi merupakan bahan mentah.

\section{Daftar Pustaka}

Badan Pusat Statistik (2018). Statistik perkebunan 2018. Badan Pusat Statistik.

Badan Pusat Statistik. (2018). Analisa komoditi ekspor 2010-2017 sektor pertanian industri dan pertambangan. Badan Pusat Statistik. https://www.bps.go.id/publication/2018/07/02/57ec2cf09e639209747dfd44/analisakomoditi-ekspor--2010-2017--sektor-pertanian--industri-dan-pertambangan.html

Barus, H. (24 Mei 2013). Ekspor Tanaman Rempah Ditargetkan USD7,72 Miliar.

INVESTOR.ID. https://investor.id/archive/ekspor-tanaman-rempah-ditargetkan-us772miliar

Elisha, L. C. (2015). Analisis ekspor kopi Indonesia ke Amerika Serikat dengan pendekatan error correction model (ECM) tahun 1981-2013 [Skripsi, Universitas Negeri

Semarang]. UNNES Repository. http://lib.unnes.ac.id/22252/

Gujarati, D. (2015). Ekonometrika dasar (Edisi ke-6). Erlangga.

Malian, A. H., Rachman, B., \& Djulin, A. (2016). Permintaan ekspor dan daya saing panili di Provinsi Sulawesi Utara. Jurnal Agro Ekonomi, 22(1). https://doi.org/10.21082/jae.v22n1.2004.26-45

Martha Ayuningsih, N. L. S., \& Setiawina, N. D. (2014). Pengaruh kurs dolar Amerika Serikat, jumlah produksi dan luas lahan terhadap volume ekspor kayu manis 
Indonesia Periode 1992-2011 Serta Daya Saingnya. E-Jurnal Ekonomi Pembangunan Universitas Udayana, 3(8), 366-375.

https://ojs.unud.ac.id/index.php/eep/article/view/9146

Mufidah, L., \& Fahmi, I. (2014). Faktor-faktor yang memengaruhi volume ekspor kayu manis Indonesia ke negara tujuan ekspor terbesar [Skripsi, Institut Pertanian Bogor]. IPB University Scientific Repository. https://repository.ipb.ac.id/handle/123456789/73308

Muttoharoh, V., Nurjanah, R., \& Mustika, C. (2018). Daya saing dan faktor-faktor yang mempengaruhi ekspor kopi Arabika Indonesia di pasar internasional. E-Jurnal Perspektif Ekonomi Dan Pembangunan Daerah, 7(3), 127-136. https://doi.org/10.22437/pdpd.v7i3.6904

Pribadi, E. R. (2016). Perkembangan produksi dan ekspor kayu manis Indonesia. Warta Penelitian Dan Pengembangan Tanaman Industri, 22(2), 10-14. https://perkebunan.litbang.pertanian.go.id/dbasebun/asset_dbasebun/43.PDF

Rifin, A. (2013). Competitiveness of Indonesia's cinnamons export in the world market. International Journal of Trade, Economics and Finance, 4(5), 279-281. https://doi.org/10.7763/IJTEF.2013.V4.301

Setyowati, D. (13 Juni 2017). Gubernur BI: 3 sebab Rupiah sulit menguat lagi ke 9000 per US\$. Katadata. https://katadata.co.id/pingitaria/finansial/5e9a564a4e645/tiga-alasannilai-tukar-rupiah-sulit-kembali-ke-level-rp-9000-per-us

United Nations Commodity Trade Statistics Database. (2018). Data Volume Ekspor Kayu Manis Indonesia ke USA Tahun 2000-2017. United Nations. https://comtrade.un.org/Data 